\title{
OPTIMAL KONTROL MODEL DINAMIK GLUKOSA, INSULIN, MASSA SEL-ß, DAN RESEPTOR INSULIN PADA PENYAKIT DIABETES MELITUS TIPE 2 DENGAN PENGATURAN AKTIVITAS FISIK DAN POLA MAKAN PENDAHULUAN
}

\author{
Marwan'1, R. Ratianigsih², A. I.Jaya ${ }^{3}$ \\ 1,2,3 Program Studi Matematika Jurusan Matematika FMIPA Universitas Tadulako \\ Jalan Soekarno-Hatta Km. 09 Tondo, Palu 94118, Indonesia. \\ 1marwan_math09@yahoo.com,2,3ratianingsih@yahoo.com
}

\begin{abstract}
Diabetes mellitus is a metabolic disorder characterized by increased blood glucose resulting from insulin production disruption or interruption due to the action of insulin or both. The two types of diabetes mellitus are: type 1 of diabetes mellitus (DMT1) in which the body lacks insulin due to an autoimmune attack on the $\beta$ cells and type 2 of diabetes mellitus (DMT2). In Case of it, there are two main issues, namely insulin resistance and impaired insulin secretion. Diabetes mellitus is a chronic disease can not be cured, it can only be controlled with a healthy lifestyle. Many methods developed to study a disease, one of which is the mathematical model. In this study, revision $\beta I G$ models that represent the interactions between glucose $(G)$, insulin (I), the beta cells $(\beta)$ and insulin receptor $(\mathrm{R})$ will be added to the controller parameters $u_{1}$ dan $u_{2}$ respectively - also a portrait of the control parameter c ( the rate of release of glucose by insulin) with physical activity with exercise and $a$ control parameter (the rate of glucose production, by the liver) with a set pattern of food. By using the Pontryagin maximum principle for controller parameters $u_{1}$ and Pontryagin's minimum $u_{2}$ controller parameters. With the controller equation $u_{1}=$ $\operatorname{maks}\left\{\min \left[\frac{\lambda_{1}(-c R I G)}{C_{1}}, 0.9\right], 0.1\right\}$ dan $\left.u_{2}=\operatorname{maks}\left\{\min \left[\frac{a \lambda_{1}}{C_{1}}, 0.9\right], 0.1\right\}, 0.1\right\}$ shows that the optimal level of control $u_{1}=$ $90 \%$ and $u_{2}=90 \%$. Comparison of the two control schemes also in a normal condition shows that the food habit controlling is more significant by better comparihs to the physical activity in keeping the body's blood.
\end{abstract}

Keyword : Diabetes Mellitus, Maximum dan Minimum Pontryagin,Optimal Control

\section{ABSTRAK}

Diabetes melitus merupakan penyakit gangguan metabolisme yang ditandai dengan meningkatnya glukosa darah sebagai akibat dari gangguan produksi insulin atau gangguan kinerja insulin atau karena kedua-duanya.Terdapat dua tipe diabetes melitus yaitu: diabetes melitus tipe 1 (DMT1) dimana tubuh kekurangan hormon insulin karena serangan autoimun pada sel $\beta$ dan yang kedua Diabetes Melitus tipe 2 (DMT2) dimana terdapat dua masalah utama yaitu resistensi insulin dan gangguan sekresi insulin. Diabetes melitus merupakan suatu penyakit yang bersifat kronis, tidak dapat disembuhkan, hanya bisa dikontrol dengan pola hidup sehat.Banyak cara yang 
dikembangkan untuk mempelajari suatu penyakit, salah satunya adalah dengan model matematika. Pada penelitian ini, revisi model $\beta I G$ yang merepresentasikan interaksi antara kadar glukosa (G), insulin (I), sel beta $(\beta)$ dan reseptor insulin $(\mathrm{R})$ akan ditambahkan dengan parameter pengontrol $u_{1}$ dan $u_{2}$ secara berturut - turut mengambarkan pengontrolan parameter c (laju pelepasan glukosa oleh insulin) dengan aktivitas fisik dengan berolahraga dan pengontrolan parameter a (laju produksi glukosa, oleh hati) dengan mengatur pola makanan. Dengan menggunakan prinsip maksimum pontryagin untuk parameter pengontrol $u_{1}$ dan minimum pontryagin untuk parameter pengontrol $u_{2}$. Dengan persamaan pengontrol $u_{1}=\operatorname{maks}\left\{\min \left[\frac{\lambda_{1}(-c R I G)}{C_{1}}, 0.9\right], 0.1\right\}$ dan $u_{2}=$ $\operatorname{maks}\left\{\min \left[\frac{a \lambda_{1}}{c_{1}}, 0.9\right], 0.1\right\} \quad$ menunjukan bahwa tingkat pengontrolan optimal $u_{1}=90 \%$ dan $u_{2}=90 \%$. Perbandingan terhadap kedua skema pengontrolan memperlihatkan bahwa pengaturan pola makan lebih signifikan dibandingkan dengan aktivitas dalam mengatur gulah darah tubuh.

\section{Kata Kunci $\quad$ : Diabetes Melitus, Kontrol Optimal, Maksimum dan Minimum Pontryagin}

\section{LATAR BELAKANG}

Diabetes melitus merupakan penyakit yang ditandai dengan meningkatnya kadar glukosa di dalam darah yang melebihi batas normal. Hal ini disebabkan karena tubuh tidak dapat melepaskan atau menggunakan insulin secara adekuat. Insulin adalah hormon yang dilepaskan oleh pankreas dan merupakan zat utama yang bertanggung jawab untuk mempertahankan kadar gula darah dalam tubuh agar tetap dalam kondisi seimbang. Insulin berfungsi sebagai alat yang membantu gula berpindah ke dalam sel sehingga bisa menghasilkan energi atau disimpan sebagai cadangan energi (Mahdiana, 2010).

Di Indonesia diabetes melitus dikenal dengan istilah penyakit gula darah atau kencing manis.Terdapat dua tipe diabetes melitus yaitu: diabetes melitus tipe 1 (DMT1) dimana tubuh kekurangan hormon insulin karena serangan autoimun pada sel $\beta$, biasanya terjadi pada anak-anak dan remaja dan perkembangannya berlangsung cepat, dan yang kedua diabetes melitus tipe 2 (DMT2) dimana hormon insulin dalam tubuh tidak dapat berfungsi dengan semestinya, biasanya terkait dengan kegemukan dan beberapa kasus kehamilan serta baru terjangkit pada usia di atas 40 tahun.

Para dokter mengatakan bahwa diabetes melitus merupakan "mother of disease", karena orang dengan diabetes memiliki risiko yang sangat tinggi untuk menjadi buta, gagal ginjal, stroke dan sejumlah penyakit lainnya.Kadar glukosa darah dipengaruhi oleh faktor endogen dan eksogen.Faktor endogen yaitu humoral faktorseperti hormon insulin, glukagon, kortisol; system reseptor di otot dan sel hati. Faktor eksogen antara lain jenis dan jumlah makanan yang dikonsumsi serta aktivitas fisik yang dilakukan (Subari, 2008). 
Secara matematis, terdapat beberapa pengontrolan seperti Pole Plancement dan linear quadratic regulator merupakan strategi - strategi klasik untuk mencari pengontrol sistem.Kelemahn dari strategi-strategi ini adalah tidak dapat mengatasi ketidakpastian dari model sistem atau gangguan dari luar. Untuk mengatasi kelemahan - kelemahan ini muncullah teori kontrol optimal modern seperti maksimum pontryagin. Kelebihan teori tersebut adalah mampu mengurangi ketidakpastian dari model sistem ataupun gangguan luar (Subchan \& Zbikowski, 2009).

\section{METODOLOGI PENELITIAN}

Penelitian dilakukan sesuai prosedur dibawah ini :

1. Memulai penelitian.

2. Mengkaji literatur

3. Membangun pengontrol revisi model $\beta I G$.

4. Pengontrolan model $\beta I G$.

5. Menentukan penyelesaian kontrol optimal.

Pada penelitian ini kontrol optimal diselesaikan dengan metode maksimum - minimum Pontryagin. Adapun langkah-langkahnya sebagai berikut:

a. Menentukan fungsi tujuan.

b. Menentukan fungsi Hamiltonian.

c. Sistem memenuhi persamaan state, co-state dan kondisi stasioner.

d. Mensubtitusi hasil yang didapatkan dari kondisi stasioner ke sistem

6. Melakukan simulasi dengan software Matlab.

7. Menyimpulkan hasil penelitian.

\section{HASIL DAN PEMBAHASAN}

\subsection{Membangun Pengontrol Revisi Model $\beta I G$}

Dalam penelitian ini, dibahas 2 skema pengaturan kadar glukosa darah pada penyakit diabetes melitus yaitu skema I dengan memaksimumkan laju pelepasan glukosa dengan insulin melalui pengaturan aktivitas fisik dan skema II dengan meminimumkan laju produksi glukosa oleh hati dengan pola makanan yang sehat.

Secara matematis pengontrolan dilakukan dengan melibatkan parameter pengontrol $u_{1}$ untuk mengontrol parameter $\mathrm{c}$ sehingga laju pelepasan glukosa dengan insulin maksimum dan $u_{2}$ untuk mengontrol parameter a sehingga laju produksi glukosa oleh hati minimum. Fungsi tujuan yang dibangun untuk masing - masing skema pengotrolan adalah dengan menentukan suatu performance indeks $(P /)$ secara berturut - turut: 
1. Skema I

$P I_{1}=\frac{1}{2} \int_{t_{0}}^{t_{a}}\left(C_{1} u^{2}+C_{2} I^{2}-C_{3} R^{2}\right) d t$

2. Skema II

$P I_{2}=\frac{1}{2} \int_{t_{0}}^{t_{a}}\left(C_{1} u^{2}+C_{2} G^{2}\right) d t$

\subsection{Pengontrolan Revisi Model $\beta$ IG}

\section{Skema I}

Pengontrolan revisi model $\beta I G$ dengan pengaturan aktivitas fisik dirancang sebagai berikut:

$\frac{d G}{d t}=a-\left(b+u_{1} c R I\right) G \ldots \ldots$
$\frac{d I}{d t}=\frac{s \beta G^{2}}{(1+R)\left(e+G^{2}\right)}-f I-f R I$
$\frac{d \beta}{d t}=\left(-g+h G-m G^{2}\right) \beta .$.
$\frac{d R}{d t}=J(1-R)-k I R-l R .$.

\section{Skema II}

Pengontrolan revisi model $\beta$ IG dengan pengaturan pola makan dirancang sebagai berikut:

$$
\begin{aligned}
& \frac{d G}{d t}=\left(1-u_{2}\right) a-(b+c R I) G \ldots \\
& \frac{d I}{d t}=\frac{s \beta G^{2}}{(1+R)\left(e+G^{2}\right)}-f I-f R I \ldots \ldots \ldots \\
& \frac{d \beta}{d t}=\left(-g+h G-m G^{2}\right) \beta \ldots \ldots \ldots \ldots \\
& \frac{d R}{d t}=J(1-R)-k I R-l R \ldots \ldots \ldots \ldots
\end{aligned}
$$

\subsection{Penyelesaian Optimal Kontrol}

\section{Skema I}

Hal yang pertama dilakukan untuk menyelesaikan optimal kontrol adalah menentukan fungsi Hamiltonian sebagai berikut:

$$
\begin{aligned}
H=P I+\lambda f(\dot{\mathrm{x}}(\mathrm{t}), \mathrm{u}(\mathrm{t}), \mathrm{t}) & \\
H=\frac{1}{2} C_{1} u_{1}{ }^{2}+\frac{1}{2} C_{2} I^{2}- & \frac{1}{2} C_{3} R^{2}+\lambda_{1}\left(a-\left(b+u_{1} c R I\right) G\right) \\
& +\lambda_{2}\left(\frac{s \beta G^{2}}{(1+R)\left(e+G^{2}\right)}-f I-f R I\right) \\
+\lambda_{3}\left(\left(-g+h G-m G^{2}\right) \beta\right)+ & \lambda_{4}(J(1-R)-k I R-l R) \ldots \ldots \ldots \ldots \ldots \ldots \ldots \ldots
\end{aligned}
$$

melalui persamaan (11) diperoleh persamaan state, co-statedan kondisi stasioner sebagai berikut.

a. Kondisi State
$\dot{G}=\frac{\partial H}{\partial \lambda_{1}}=a-\left(b+u_{1} c R I\right) G$ 


$$
\begin{aligned}
& \dot{I}=\frac{\partial H}{\partial \lambda_{2}}=\frac{s \beta G^{2}}{(1+R)\left(e+G^{2}\right)}-f I-f R I \ldots \\
& \dot{\beta}=\frac{\partial H}{\partial \lambda_{3}}=\left(-g+h G-m G^{2}\right) \beta \ldots . \\
& \dot{R}=\frac{\partial H}{\partial \lambda_{4}}=J(1-R)-k I R-l R \ldots .
\end{aligned}
$$

dengan kondisi batas sebagai berikut :

$G(0)=G_{0} \geq 0 ; I(0)=I_{0} \geq 0 ; \beta(0)=\beta_{0} \geq 0 ; R(0)=R_{0} \geq 0$.

b. Persamaan Co-State

$$
\begin{aligned}
& \dot{\lambda_{1}}=-\frac{\partial H}{\partial G}=-\lambda_{1}\left(-\left(b+u_{1} c R I\right)\right)-\lambda_{2}\left(\frac{2 s \beta G}{(1+R)\left(e+G^{2}\right)}-\frac{2 s \beta G^{3}}{(1+R)\left(e+G^{2}\right)^{2}}\right) \\
& -\lambda_{3}(h-2 m G) \beta \\
& \dot{\lambda_{2}}=-\frac{\partial \mathrm{H}}{\partial \mathrm{I}}=-C_{2} I+\lambda_{1} u_{1} c R G+\lambda_{2}(f+f R)+\lambda_{4}(k R) \\
& \dot{\lambda_{3}}=-\frac{\partial \mathrm{H}}{\partial \beta}=-\frac{\lambda_{2} s G^{2}}{(1+R)\left(e+G^{2}\right)}-\lambda_{3}\left(-g+h G-m G^{2}\right) \\
& \dot{\lambda_{4}}=-\frac{\partial \mathrm{H}}{\partial \mathrm{R}}=C_{3} R+\lambda_{1}\left(u_{1} c I G\right)-\lambda_{2}\left(\frac{-s \beta G^{2}}{(1+R)\left(e+G^{2}\right)}-f I\right)-\lambda_{4}(-J-k I-l)
\end{aligned}
$$

c. Kondisi Stasioner

$$
\frac{\partial H}{\partial u_{1}}=0=>C_{1} u_{1}+\lambda_{1}(-c R I G)=0=>u_{1}=\frac{\lambda_{1}(-c R I G)}{C_{1}}
$$

\section{Skema II}

Hal yang pertama dilakukan untuk menyelesaikan optimal kontrol adalah menentukan fungsi Hamiltonian sebagai berikut:

$$
\begin{aligned}
& H=P I+\lambda f(\dot{\mathrm{x}}(\mathrm{t}), \mathrm{u}(\mathrm{t}), \mathrm{t}) \\
& H=\frac{1}{2} C_{1} u_{2}{ }^{2}+\frac{1}{2} C_{2} G^{2}+\lambda_{1}\left(\left(1-u_{2}\right) a-(b+c R I) G\right)+\lambda_{2}\left(\frac{s \beta G^{2}}{(1+R)\left(e+G^{2}\right)}-f I-f R I\right) \\
& +\lambda_{3}\left(\left(-g+h G-m G^{2}\right) \beta\right)+\lambda_{4}(J(1-R)-k I R-l R)
\end{aligned}
$$

melalui persamaan (21) diperoleh persamaan state, co-statedan kondisi stasioner.

a. Kondisi State

$$
\begin{aligned}
& \dot{G}=\frac{\partial H}{\partial \lambda_{1}}=\left(1-u_{2}\right) a-(b+c R I) G \\
& \dot{I}=\frac{\partial H}{\partial \lambda_{2}}=\frac{s \beta G^{2}}{(1+R)\left(e+G^{2}\right)}-f I-f R I \text {. } \\
& \dot{\beta}=\frac{\partial H}{\partial \lambda_{3}}=\left(-g+h G-m G^{2}\right) \beta \\
& \dot{R}=\frac{\partial H}{\partial \lambda_{4}}=J(1-R)-k I R-l R
\end{aligned}
$$

dengan kondisi batas sebagai berikut :

$G(0)=G_{0} \geq 0 ; I(0)=I_{0} \geq 0 ; \beta(0)=\beta_{0} \geq 0 ; R(0)=R_{0} \geq 0$.

b. Persamaan Co-State

$$
\begin{aligned}
& \dot{\lambda_{1}}=-\frac{\partial H}{\partial G}=-C_{2} G+\lambda_{1}(-(b+c R I))-\lambda_{2}\left(\frac{2 s \beta G}{(1+R)\left(e+G^{2}\right)}-\frac{2 s \beta G^{3}}{(1+R)\left(e+G^{2}\right)^{2}}\right) \\
& -\lambda_{3}(h-2 m G) \\
& \dot{\lambda_{2}}=-\frac{\partial \mathrm{H}}{\partial \mathrm{I}}=\lambda_{1}(c R G)+\lambda_{2}(f+f R)+\lambda_{4}(k R) \\
& \dot{\lambda_{3}}=-\frac{\partial \mathrm{H}}{\partial \beta}=-\left(\frac{\lambda_{2} s G^{2}}{(1+R)\left(e+G^{2}\right)}+\lambda_{3}\left(-g+h G-m G^{2}\right)\right) \text {. }
\end{aligned}
$$




$$
\dot{\lambda_{4}}=-\frac{\partial \mathrm{H}}{\partial \mathrm{R}}=\lambda_{1}(c I G)-\lambda_{2}\left(-\frac{-s \beta G^{2}}{(1+R)\left(e+G^{2}\right)}-f I\right)-\lambda_{4}(-J-k I-l)
$$

c. Kondisi stasioner

$$
\frac{\partial H}{\partial u_{2}}=0=>C_{1} u_{2}-\lambda_{1} a=0=>u_{2}=\frac{a \lambda_{1}}{C_{1}} .
$$

\subsection{Simulasi}

Simulasi dilakukan untuk beberapa kondisi awal dimana $G(0), I(0), \beta(0)$ dan $R(0)$ yang diambil dari 3 titik tetap yang telah dianalisis kestabilannya oleh (Listiandini, 2011) sedemikian hingga mencerminkan kategori normal, rentan dan parah. Hal tersebut didasarkan pada interval umum pengukuran laboratorium.

\section{Skema I}

Persamaan (20) memberikan nilai $u_{1}$ yang merupakan tingkat pengontrolan untuk meminimalisir Insulin dan meningkatkan Reseptor Insulin melalui aktivitas fisik, maka keberhasilannya diukur dalam persentase yaitu berkisar $0-100 \%$. Pada penelitian ini diasumsikan bahwa tingkat keberhasilan program paling rendah adalah $10 \%$ dan paling tinggi adalah $90 \%$ sehingga kondisi batasnya menjadi $0.1 \leq u_{1} \leq 0.9$ atau dapat dituliskan sebagai berikut:

$u_{1}=\operatorname{maks}\left\{\min \left\{\frac{\lambda_{1}(-c R I G)}{C_{1}}, 0.9\right\}, 0.1\right\}$

Proses simulasi dibagi menjadi beberapa kondisi, sebagai berikut :

\section{a. Kondisi Normal}

Untuk simulasi digunakan nilai - nilai parameter pada Tabel 1 dan kondisi awal $G(0)=$ 82, $\mathrm{I}(0)=12.7, \beta(0)=856.95$ dan $\mathrm{R}(0)=0.84$ yang mengindikasikan kondisi normal. Untuk kepentingan penggambaran perubahan variabel $G, I, \beta$ dan $R$ terhadap waktu, interval waktu 24 jam ditransformasi dalam interval $[0,1]$.
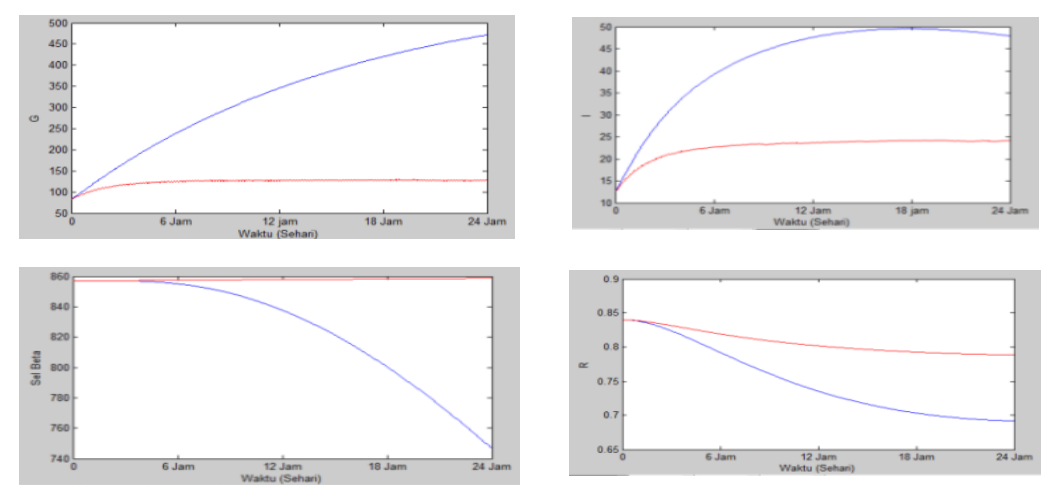

Gambar1 : Kurva G, I, $\beta$ dan R terhadap waktu untuk kondisi normal dengan c sebagai parameter yang dikontrol 
Setiap kurva pada Gambar 1 secara berturut - turut memperlihatkan perubahan kadar glukosa $(G)$, insulin $(I)$, sel beta $(\beta)$ dan reseptor insulin $(R)$ terhadap waktu aktivitas pengontrol dengan garis yang berwarna biru dan dengan pengontrol berwarna merah. Nilai glukosa $\mathrm{G}$ yang mula - mula memiliki kadar glukosa 82 akan meningkat mencapai 472 jika tidak melakukan aktivitas fisik. Namun bila melakukannya, kadar gula dapat dijaga sebesar 128. Hasil yang serupa juga diperlihatkan pada nilai I yang merepresentasikan perubahan insulin terhadap waktu. Kondisi berbeda diperlihatkan pada kurva sel beta $\beta$ sebagai penghasil insulin dan reseptor insulin $\mathrm{R}$ yang merupakan protein pada permukaan sel yang mengikat insulin yang bila tidak bekerja dengan baik akan menyebabkan berkurangnya tingkat penyerapan glukosa oleh tubuh. Hal ini terlihat dari kurva biru pada gambar tersebut yang terus menurun dibawah kurva berwarna merah.

Selain menurunkan kadar glukosa $\mathrm{G}$ pengontrolan parameter c juga menggambarkan penurunan I yang menunjukan penggunaan insulin yang efesien, peningakatan $R$ dan $\beta$ yang mengindikasikan sel $\beta$ yang akan tetap bekerja menghasilkan insulin. Simulasi ini yang menunjukan bahwa keberhasilan pengaturan aktivitas fisik untuk mengendalikan kadar glukosa pada penyakit diabetes melitus perlu dilakukan dengan tingkat aktivitas fisik yang maksimal. Hal ini ditunjukan dari nilai tingkat pengontrol yang tinggi, yaitu sebesar $u_{1}=0.9$.

\section{b. Kondisi Rentan Penyakit}

Untuk simulasi digunakan nilai - nilai parameter pada Tabel 1 dan kondisi awal $G(0)=$ $145, \mathrm{I}(0)=6.04, \beta(0)=208.31$ dan $\mathrm{R}(0)=0.88$ mengindikasikan kondisi rentan penyakit. Untuk kepentingan penggambaran perubahan variabel $\mathrm{G}, \mathrm{I}, \beta$ dan $\mathrm{R}$ terhadap waktu, interval waktu 24 jam ditransformasi dalam interval $[0,1]$.
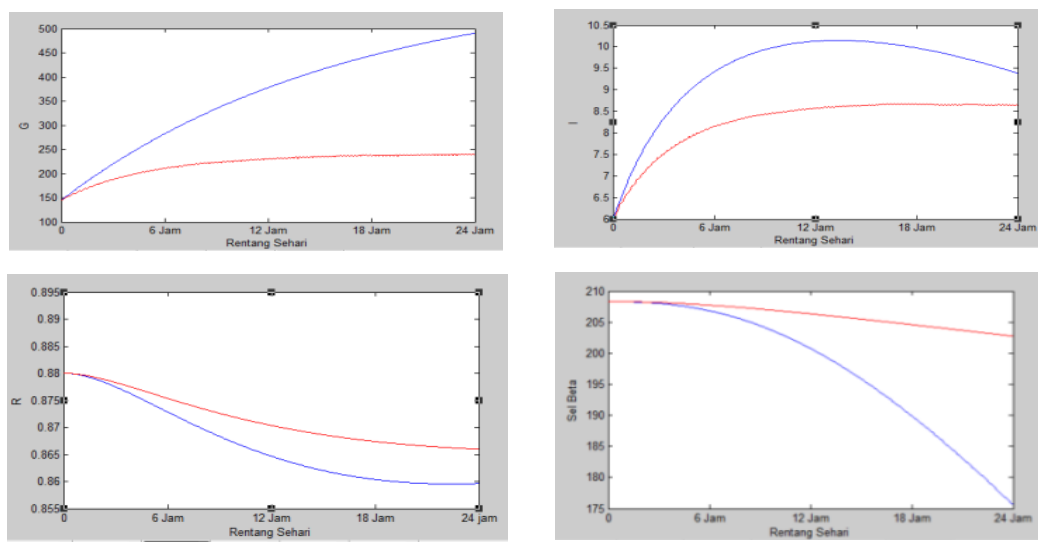

Gambar2 : Kurva G, I, $\beta$ dan R terhadap waktu untuk kondisi rentan dengan c sebagai parameter yang dikontrol 
Gambar 2 memperlihatkan bahwa kadar glukosa awal berada dalam kategori rentan, bila tidak dilakukan pengontrolan peningkatan nilai glukosa $G$ terhadap waktu akan lebih tajam bila dibandingkan dengan kategori normal. Pengontrolan aktivitas fisik terlihat masih cocok dipilih untuk mengontrol kadar glukosa untuk kategori rentan. Hal ini terjadi karena sekalipun tidak dapat menahan penurunan nilai sel beta $\beta$ dan rseptor insulin $R$, namun mampu meningkatkan produksi insulin I. Simulasi ini yang menunjukkan bahwa keberhasilan pengaturan aktivitas fisik untuk mengendalikan kadar glukosa pada penyakit diabetes melitus perlu dilakukan dengan tingkat aktivitas fisik yang maksimal. Hal ini ditunjukan dari nilai tingkat pengontrol yang tinggi, yaitu sebesar $u_{1}=0.9$.

\section{c. Kondisi Penyakit Diabetes Parah}

Untuk simulasi digunakan nilai - nilai parameter pada Tabel 1 dan kondisi awal $G(0)=$ $600, \mathrm{I}(0)=0, \beta(0)=0$ dan $\mathrm{R}(0)=0.917$ mengindikasikan kondisi penyakit diabetes parah. Untuk kepentingan penggambaran perubahan variabel $\mathrm{G}, \mathrm{I}, \beta$ dan $\mathrm{R}$ terhadap waktu, interval waktu 24 jam ditransformasi dalam interval $[0,1]$.

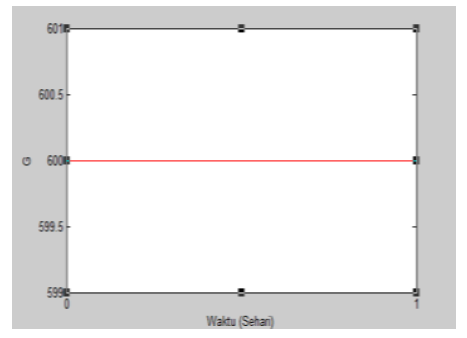

Gambar3 : Kurva G terhadap waktu untuk kondisi parah dengan c sebagai parameter yang dikontrol

Gambar 3 menunjukan bahwa mengontrol aktivitas fisik tidak dapat digunakan untuk menurunkan kadar glukosa kategori parah karena nilai G konstan pada nilai 600 seiring dengan pertambahan waktu. Ketidakmampuan insulin I sel beta $\beta$ dan reseptor insulin $R$ dalam mengotrol kadar glukosa $\mathrm{G}$ penderita penyakit diabetes parah mengakibatkan kurva I, $\beta$ dan $\mathrm{R}$ tidak terplot pada gambar 3 .

\section{Skema II}

Persamaan (30) memberikan nilai $u_{2}$ yang merupakan tingkat pengontrolan untuk meminimalisir glukosa melalui pengaturan pola makan, maka keberhasilannya diukur dalam persentase yaitu berkisar $0-100 \%$. Pada penelitian ini diasumsikan bahwa tingkat keberhasilan program paling rendah adalah $10 \%$ dan paling tinggi adalah $90 \%$ sehingga kondisi batasnya menjadi $0.1 \leq u_{2} \leq 0.9$ atau dapat dituliskan sebagai berikut:

$u_{2}=\operatorname{maks}\left\{\min \left\{\frac{a \lambda_{1}}{c_{1}}, 0.9\right\}, 0.1\right\}$ 
Proses simulasi dibagi menjadi beberapa kondisi, sebagai berikut :

\section{a. Kondisi Normal}

Untuk simulasi digunakan nilai - nilai parameter pada Tabel 1 dan kondisi awal $G(0)=$ $82, I(0)=12.7, \beta(0)=856.95$ dan $R(0)=0.84$ yang mengindikasikan kondisi normal. Untuk kepentingan penggambaran perubahan variabel $\mathrm{G}, \mathrm{I}, \beta$ dan $\mathrm{R}$ terhadap waktu, interval waktu 24 jam ditransformasi dalam interval $[0,0.1]$.
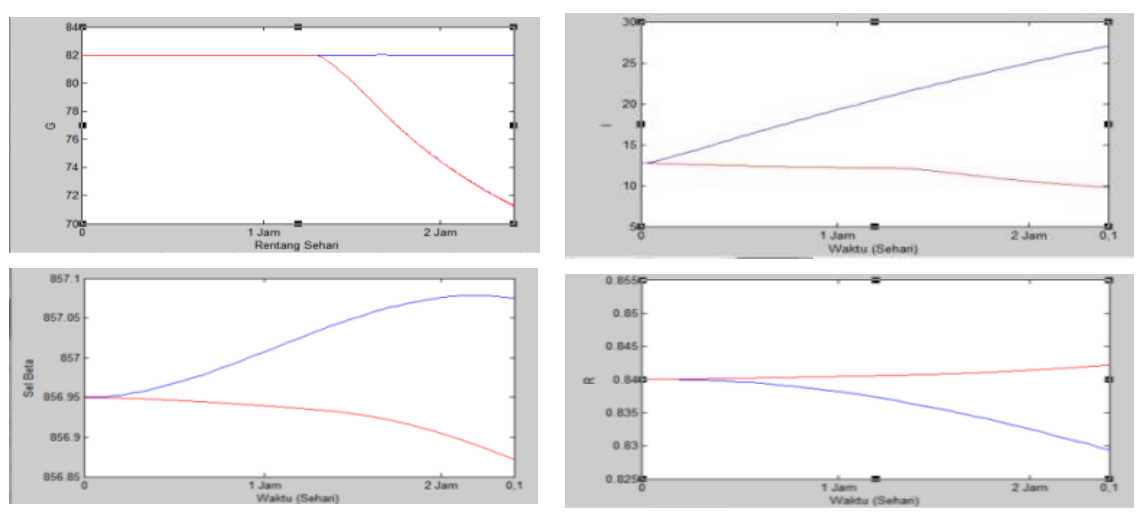

Gambar 4 : Kurva G, I, $\beta$ dan R terhadap waktu untuk kondisi normal dengan $a$ sebagai parameter yang dikontrol

Jika pada Gambar 1.dan Gambar 2. nilai G setelah dikontrol masih meningkat, Gambar 4. memperlihatkan bahwa nilai $\mathrm{G}$ setelah dikontrol ternyata mengalami penurunan yang cukup signifikan dalam rentan waktu 0.1 hari atau sekitar 2.4 jam. Hasil ini cukup realistis, mengingat perubahan kadar glukosa terjadi sekitar 2 jam setelah makan dan salah satu cara menekan nilai parameter a (laju produksi glukosa, oleh hati) yakni dengan pengaturan pola makanan. Pengaturan ini perlu diperhatikan setelah waktu 2 jam agar kadar glukosa tidak terus menurun. Nilai insulin I pada Gambar 4.yang terlihat menurun tidak seperti pada pengaturan aktivitas fisik yang naik, menunjukan bahwa efektifitas penggunaan insulin mengikuti perubahan nilai glukosa G. Reseptor insulin R setelah dikontrol dapat terjaga sehingga tidak mengalami penurunan sebagai mana nilai $R$ aktivitas pengontrol. Simulasi ini juga menunjukan bahwa keberhasilan pengaturan pola makan untuk mengendalikan kadar glukosa pada penyakit diabetes melitus perlu dilakukan dengan tingkat pola makan yang maksimal. Hal ini ditunjukan dari nilai tingkat pengontrol yang tinggi, yaitu sebesar $u_{1}=0.9$.

\section{b. Kondisi Rentan Penyakit}

Untuk simulasi digunakan nilai - nilai parameter pada Tabel 1 dan kondisi awal $G(0)=$ $145, \mathrm{I}(0)=6.04, \beta(0)=208.31$ dan $\mathrm{R}(0)=0.88$ mengindikasikan kondisi rentan penyakit. 
Untuk kepentingan penggambaran perubahan variabel G, I, $\beta$ dan $\mathrm{R}$ terhadap waktu, interval waktu 24 jam ditransformasi dalam interval $[0,0.1]$.
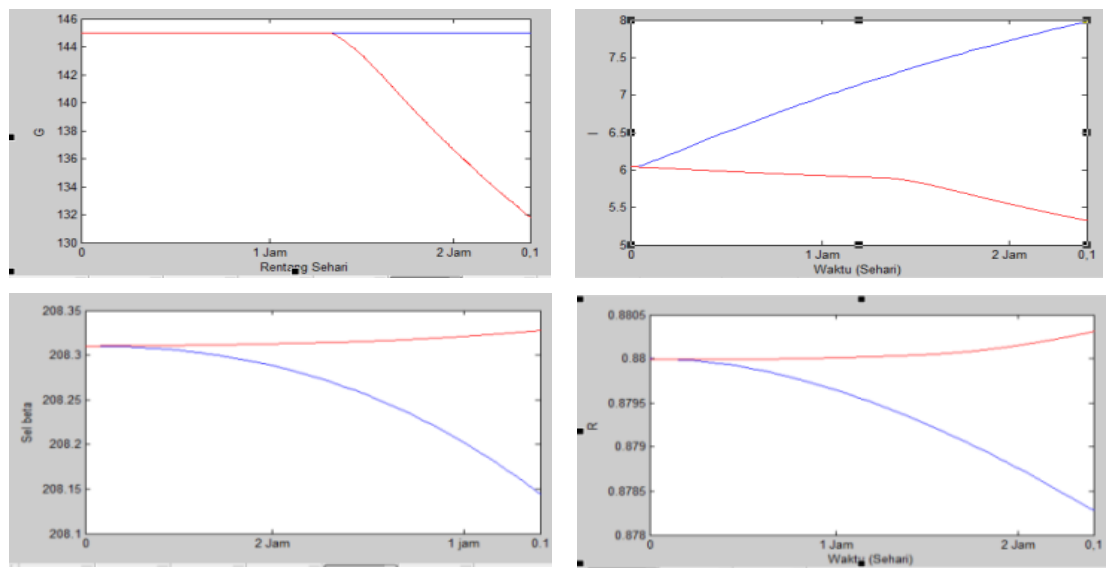

Gambar5 : Hubungan $\mathrm{G}, \mathrm{I}, \beta$ dan R pada titik rentan revisi model $\beta \mathrm{IG}$ dengan $a$ sebagai parameter pengontrolan

Pada Gambar 4 dan Gambar 5 memiliki interpretasi yang sama. Perbedaan terjadi pada sel beta $\beta$ dimana pada kategori rentan tidak lagi terjadi penurunan sel beta $\beta$ seiring dengan pertambahan waktu.Simulasi ini juga menunjukan bahwa keberhasilan pengaturan pola makan untuk mengendalikan kadar glukosa pada penyakit diabetes melitus perlu dilakukan dengan tingkat pola makan yang maksimal. Hal ini ditunjukan dari nilai tingkat pengotrol yang tinggi, yaitu sebesar $u_{1}=0.9$.

\section{c. Kondisi Penyakit Diabetes Parah}

Untuk simulasi digunakan nilai - nilai parameter pada Tabel 1 dan kondisi awal $G(0)=$ $600, I(0)=0, \beta(0)=0$ dan $R(0)=0.917$ mengindikasikan kondisi penyakit diabetes parah. Untuk kepentingan penggambaran perubahan variabel $\mathrm{G}, \mathrm{I}, \beta$ dan $\mathrm{R}$ terhadap waktu, interval waktu 24 jam ditransformasi dalam interval $[0,1]$.

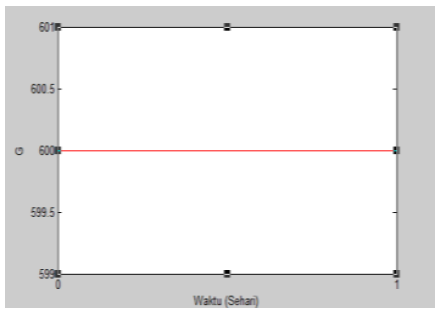

Gambar 6 : Kurva G terhadap waktu untuk kondisi parah dengan a sebagai parameter yang dikontrol 
Gambar 6.menunjukan bahwa mengontrol aktivitas fisik tidak dapat digunakan untuk menurunkan kadar glukosa kategori parah karena nilai $G$ konstan pada nilai 600 seiring dengan pertambahan waktu. Ketidakmampuan insulin I sel beta $\beta$ dan reseptor insulin $R$ dalam mengontrol kadar glukosa $\mathrm{G}$ penderita penyakit diabetes parah mengakibatkan kurva I, $\beta$ dan $\mathrm{R}$ tidak terplot pada Gambar 6.

\subsection{Pembahasan}

Hasil yang diperoleh memperlihatkan bahwa pengontrolan aktivitas fisik yang dilakukan pada parameter $c$ (laju pelepasan glukosa karena insulin) dapat menekan peningkatan nilai $G$ secara signifikan. Nilai $G$ tetap mengalami peningkatan untuk kategori normal maupun rentan namun tetap terjaga pada kadar yang normal yakni $<200 \mathrm{mg} / \mathrm{dL}$. Efektifitas penggunaan insulin juga dapat terlihat, peningkatan nilai I dengan pengontrol tidak sesignifikan peningkatan nilai I aktivitas pengontrol.Nilai $\beta$ dan $R$ untuk kategori normal juga tetap stabil, walaupun untuk kategori rentan mengalami penurunan.Dalam kondisi ini penurunan tidak sesignifikan penurunan pada nilai $\beta$ dan $R$ aktivitas pengontrol.

\section{KESIMPULAN}

Berdasarkan penelitian yang telah dilakukan dengan melihat hubungan model dinamik glukosa, insulin, massa sel- $ß$, dan reseptor insulin pada penyakit diabetes melitus tipe 2 dengan pengaturan aktivitas fisik dan pola makanan, diperoleh beberapa kesimpulan bahwa :

1. Fungsi Hamiltonian memberikan persamaan state, co-state dan kondisi stasioner. Dengan menyelesaikan persamaan-persamaan tersebut, diperoleh kontrol optimal untuk parameter $u_{1}$ dan $u_{2}$ sebagai berikut $: u_{1}=\operatorname{maks}\left\{\min \left[\frac{\lambda_{1}(-C R I G)}{C_{1}}, 0.9\right], 0.1\right\}$ $u_{2}=\operatorname{maks}\left\{\min \left[\frac{a \lambda_{1}}{c_{1}}, 0.9\right], 0.1\right\}$.

2. Pengontrolan optimal dari model dinamik glukosa, insulin, massa sel- $\beta$, dan reseptor insulin pada penyakit diabetes melitus tipe 2 dapat dilakukan dengan memaksimalkan nilai parameter $\mathrm{c}$ atau meminimumkan nilai parameter $a$.

3. Pada pengontrolan optimal dari model dinamik glukosa, insulin, massa sel- $ß$, dan reseptor insulin pada penyakit diabetes melitus tipe 2 didapatkan bahwa pengaturan pola makan lebih signifikan dalam mengontrol kadar gula darah bila dibandingkan dengan pengaturan aktivitas fisik. 


\section{DAFTAR PUSTAKA}

[1] Mahdiana R. 2010.Mencegah Penyakit Kronis Sejak Dini. Tora Book.Jogjakarta .

[2] Listiandini E. 2011.Model Matematika Dinamika Glukosa, Insulin, Massa Sel-B, Dan Reseptor Insulin Pada Penyakit Diabetes Melitus Tipe 2.Institut Pertanian Bogor.

[3] Subari, N.D. 2008.Hubungan Dukungan Keluarga Dengan Keaktifan Penderita Diabetes Mellitus Rumah Sakit Dr. Oen Solo Baru.Abstrak skripsi.

[4] Subchan, Zbikowski R. 2009. Computational Optimal Control.Cranfield University.Dhrivenham. 